\title{
Genetic variability in the mitochondrial DNA of the Danish Pine marten
}

\author{
C. Pertoldi ${ }^{1,2, x}$, J. Muñ oz ${ }^{3, \times}$, A. B. Madsen ${ }^{4}$, J. S. F. Barker ${ }^{5}$, D. H. Andersen ${ }^{1}$, H. J. Baagøe ${ }^{6}$, M. Birch ${ }^{6}$ \& \\ V. Loeschcke ${ }^{1}$
}

1 Department of Biological Science, Ecology and Genetics, University of Aarhus, Ny Munkegade, Aarhus C, Denmark

2 Mammal Research Institute, Polish Academy of Sciences, Bialowieza, Poland

3 Laboratory of Molecular Ecology, Estación Biológica Doñana, CSIC. Pabellón del Perú. Avda. María Luisa, Seville, Spain

4 Department of Wildlife Ecology and Biodiversity, National Environmental Research Institute, University of Aarhus, Kalø, Rønde, Denmark

5 School of Rural Science and Agriculture, University of New England, Armidale, NSW, Australia

6 The Natural History Museum of Denmark, the Zoological Museum, Universitetsparken 15, Copenhagen, Denmark

\author{
Keywords \\ mtDNA; ancient DNA; pleistocenic \\ recolonization.

\section{Correspondence} \\ Cino Pertoldi, Department of Biological \\ Science, Ecology and Genetics, University \\ of Aarhus, Building 1540, Ny Munkegade, \\ DK-8000 Aarhus C, Denmark. \\ Fax: +45-89422722 \\ Email: biocp@nf.au.dk or \\ cpertoldi@bison.zbs.bialowieza.pl
}

${ }^{\times}$Both authors contributed equally.

\begin{abstract}
Here we study genetic differentiation and changes over time in genetic variability in the rare pine marten Martes martes. Samples from three isolated geographic regions: Jutland and Sealand (Denmark) and southern Scania (southernmost Sweden), were genotyped by sequencing the hypervariable domain of the mitochondria control region. Both recent and museum samples were analysed in order to evaluate any temporal loss of genetic variability. Eight haplotypes were found. Two were main haplotypes shared by individuals from all three regions, and in all localities unique haplotypes were found. When comparing the data with previous haplotype analysis, our results suggest that at least three different haplotype groups exist in central and Northern Europe, with the samples from southern Scania being differentiated from samples previously analysed from central Sweden, and the genotypic data for Jutland and Sealand suggest a recent independent evolutionary history for the Danish pine marten.
\end{abstract}

\section{Introduction}

The pine marten Martes martes is distributed throughout Europe, but it has been subject to long-term decline in numbers in most regions (Mitchell-Jones et al., 1999). Subfossil records show that the pine marten has lived in Denmark for the last 9500 years, and it is believed to have invaded the country 11000 years ago when the area was recolonized after the latest ice age (Aaris-Sørensen, 2007; Madsen et al., 2007). At present, it is listed as rare on the national Red List (Stoltze \& Pihl, 1997). The pine marten is a habitat specialist confined to mature deciduous and coniferous forests (Domingo-Roura, 2002), has a limited dispersal ability compared with other mustelids (Kyle, Davis \& Strobeck, 2000) and a slow reproduction rate, rendering it particularly vulnerable to habitat change (Bright, 2000). Over the last century, the landscape in Denmark has undergone substantial changes. Today, it consists of large areas of open, cultivated land with a few widely dispersed fragments of natural habitat (see Caspersen, 2001). Habitat destruction and deterioration due to fragmentation are supposed to be the main cause of the decline of the pine marten in the last century (Degn \& Jensen, 1977).

Population declines have been observed in several mustelids in Denmark from the early 1960s, for example, Eurasian badger Meles meles (Pertoldi et al., 2005), weasel Mustela erminea and stoat Mustela nivalis (Pertoldi et al., 2006a), polecat Mustela putorius (Pertoldi et al., 2006b) and the Eurasian otter Lutra lutra (Pertoldi et al., 2001). The reasons for this general decline seem to be associated mainly with the intensification of agricultural practices, and consequent habitat fragmentation, increasing sharply from the beginning of the 1960s (Caspersen, 2001; Pertoldi et al., 2006a).

We hypothesized that the documented decline in population size, together with habitat fragmentation, would be reflected in (1) genetic differentiation between geographic regions and (2) changes in genetic variability over time within geographic regions. The spatial differentiation 
hypothesis was tested using samples from three isolated geographical regions: the Jutland peninsula (J) and Sealand island (S) from Denmark and the Swedish peninsula (L). The hypothesis of temporal loss of genetic variability was tested by comparing historical and recent samples from the two geographical regions ( $\mathrm{J}$ and $\mathrm{S}$ ).

\section{Material and methods}

\section{Area of study and samples}

The samples are from three geographically distinct areas separated by the sea (Jutland - Peninsula; Sealand - Island and southern Scania-southernmost Sweden). These areas were connected during and after the last glaciation (Pleistocene) until c. 8000 years ago, thus allowing dispersal and migration of Ma. martes between them during a period of c. 1500-3000 years of the post glacial period. A total of 84 samples from both recent (after 1966) and historical (before 1966) specimens were used in the genetic analyses plus one haplotype from GenBank (accession number AF336968): 52 samples came from Jutland, 26 from Sealand and six from southern Scania (Table 1). The haplotypes described by Davison et al. (2001) for Ma. martes (Hap. a, b, d, l, m, o and $\mathrm{u}$ ) from Germany, the Netherlands and the central part of Sweden were used for determining any similarity of these samples to those of our three regions of study.

\section{DNA extraction protocols}

\section{Tissues and blood samples}

Genomic DNA was extracted from 77 tissue or blood pine marten samples using the following salting-out procedure described briefly in the following paragraph. Two hundred microliters of blood was resuspended in $1 \mathrm{~mL}$ of red cell lysis buffer (RCLB, $10 \mathrm{mM}$ Tris-HCl, $5 \mathrm{mM} \mathrm{MgCl}_{2}, 10 \mathrm{mM}$ $\mathrm{NaCl}$ ) and centrifuged at $2500 \mathrm{~g}$. Pellets were resuspended in $300 \mathrm{~mL}$ of white cell lysis buffer $(10 \mathrm{mM}$ Tris- $\mathrm{HCl}, 10 \mathrm{mM}$ EDTA, $50 \mathrm{mM} \mathrm{NaCl}$ ) and incubated for $2 \mathrm{~h}$ with $10 \mathrm{~mL}$ of proteinase $\mathrm{K}\left(10 \mathrm{mg} \mathrm{mL}^{-1}\right)$ and $5 \mathrm{~mL}$ of SDS $10 \%$ at $561 \mathrm{C}$. To precipitate proteins, $170 \mathrm{~mL}$ of sodium acetate $3 \mathrm{M}$ was added and samples were spun at $10000 \mathrm{~g}$. Five hundred microliters of isopropanol was added to the supernatant containing DNA and the sample was centrifuged at $15000 \mathrm{~g}$ to precipitate DNA. Pellets were then washed with $300 \mathrm{~mL}$ of $70 \%$ ethanol and resuspended in $200 \mathrm{~mL}$ of low TE (Tris $10 \mathrm{mM} / \mathrm{EDTA} 0.1 \mathrm{mM}$ ). For tissues, the same procedure was followed, except that the RCLB lysis step was omitted.

\section{Museum samples}

From the historical samples before $1966(n=15)$ (range: 1951-1966), DNA was extracted from hair samples using standard chloroform/CTAB extraction, and from teeth using microconcentrators (Nielsen, Hansen \& Loeschcke, 1999; Pertoldi et al., 2001). Material from teeth was obtained by removing a canine tooth and drilling out the root using a $2 \mathrm{~mm}$ drill. Approximately $0.15 \mathrm{~g}$ of tooth and tooth root were collected and used for DNA extraction following the procedure of Pertoldi et al. (2006a). The drill was sterilized by heating following each collection of tooth root, in order to avoid cross contamination. Extractions of DNA from recent tissue samples were not conducted in the laboratory during the same time period as work on historical samples, and polymerase chain reaction (PCR) reagents were exposed to UV radiation in a UV cross-linker in order to degrade possible contaminating DNA (see Pertoldi et al., 2001). DNA from museum samples was isolated under sterile and non-contaminating conditions (i.e. in a special laboratory available for degraded DNA samples); therefore, the contact between recent and ancient samples and DNA was avoided during all the processes.

\section{Control region (CR) amplification and sequencing}

\section{Tissues and blood samples}

Around $350 \mathrm{bp}$ of the hypervariable domain of CR was amplified by PCR using primers LRCB1 (Davison et al., 2001) and H16498 (Shields \& Kocher, 1991). PCR reactions were carried out in $10 \mathrm{~mL}$ of final volume and $1 \mathrm{~mL}$ of DNA extract, using standard Taq polymerase and buffer (Invitrogen Corporation, Carlsbad, CA, USA) with $2 \mathrm{mM} \mathrm{MgCl}_{2}$ and $0.2 \mathrm{mM}$ of each primer as a final concentration. Thirtyfive cycles of the following thermal profile were applied: 941C, 2 min; $941 \mathrm{C}, 30 \mathrm{~s} ; 50$ 1C, $30 \mathrm{~s}$; 72 1C, 15 s; 72 1C, 7 min.

\section{Museum samples}

A first round of amplification was performed in $20 \mathrm{~mL}$ of final volume and $5 \mathrm{~mL}$ of DNA extract, using the same protocol as above, except that $2.5 \mathrm{mM} \mathrm{MgCl}_{2}$ was used and the concentration of each reagent was doubled in the reaction mix. Forty cycles of the above thermal profile were applied. A second round of amplifications was performed using $2 \mathrm{~mL}$ of PCR reactions from the first round and the internal primer LRCB3 (Davison et al., 2001) coupled with H16498. The same reaction mix and thermal profiles as for the first round were used. Single, clean bands were obtained from PCR reactions.

\section{Sequencing}

PCR products were purified using EXO-SAP IT (USB, Cleveland, $\mathrm{OH}, \mathrm{USA}$ ) and sequenced using the BigDye Terminator Kit V1.1 (Applied Biosystems, Foster City, CA, USA) and primer LRCB3. Fragments were electrophoresed on an AB310 genetic analyser; electropherograms were aligned and visually inspected using SeqScape 2.5 (Applied Biosystems) software for a final sequence fragment of $242 \mathrm{bp}$.

Sixty-nine out of 77 tissue blood $^{-1}$ samples were successfully amplified and sequenced. Forty-three DNA samples from museum specimens were subjected to two rounds of amplifications and 15 samples were sequenced successfully. 
Table 1 Sample code (Museum codes) and GenBank access number of the samples collected in Jutland (J), Sealand (S) and southern Scania (L)

\begin{tabular}{|c|c|c|c|c|}
\hline Sample code & Source $(\mathrm{J}, \mathrm{S}, \mathrm{L})$ & Date (01966/41966) & Haplotype (number) & Haplotype (GB accession number) \\
\hline 2001_3006M & $\mathrm{J}$ & 41966 & Hap. $1^{\text {a }}$ & AF336949-AF336950-AF336969 \\
\hline 2003_3014M & $\mathrm{J}$ & 41966 & Hap. $1^{\text {a }}$ & AF336949-AF336950-AF336969 \\
\hline 2001_3010M & $\mathrm{J}$ & 41966 & Hap. $1^{\mathrm{a}}$ & AF336949-AF336950-AF336969 \\
\hline 2003_3002M & $\mathrm{J}$ & 41966 & Hap. $1^{\mathrm{a}}$ & AF336949-AF336950-AF336969 \\
\hline 2001_3013L & $\mathrm{J}$ & 41966 & Hap. $1^{a}$ & AF336949-AF336950-AF336969 \\
\hline 2001_3007M & $\mathrm{J}$ & 41966 & Hap. $1^{\mathrm{a}}$ & AF336949-AF336950-AF336969 \\
\hline 2001_3011N & $\mathrm{J}$ & 41966 & Hap. $1^{\text {a }}$ & AF336949-AF336950-AF336969 \\
\hline 2005_3001M & $\mathrm{J}$ & 41966 & Hap. $1^{\text {a }}$ & AF336949-AF336950-AF336969 \\
\hline 2004_3002M & $\mathrm{J}$ & 41966 & Hap. $1^{\mathrm{a}}$ & AF336949-AF336950-AF336969 \\
\hline 2003_3018M & $\mathrm{J}$ & 41966 & Hap. $1^{a}$ & AF336949-AF336950-AF336969 \\
\hline 2006_3014M & $\mathrm{J}$ & 41966 & Hap. $1^{\mathrm{a}}$ & AF336949-AF336950-AF336969 \\
\hline 2002_3005M & $\mathrm{J}$ & 41966 & Hap. $1^{\text {a }}$ & AF336949-AF336950-AF336969 \\
\hline M7376 & $\mathrm{J}$ & 41966 & Hap. $1^{a}$ & AF336949-AF336950-AF336969 \\
\hline 2006_3001M & $\mathrm{J}$ & 41966 & Hap. $1^{\mathrm{a}}$ & AF336949-AF336950-AF336969 \\
\hline 2001_3019M & $\mathrm{J}$ & 41966 & Hap. $1^{\text {a }}$ & AF336949-AF336950-AF336969 \\
\hline CN4241 & $\mathrm{J}$ & 01966 & Hap. $1^{\text {a }}$ & AF336949-AF336950-AF336969 \\
\hline CN4203 & $\mathrm{J}$ & O1966 & Hap. $1^{\mathrm{a}}$ & AF336949-AF336950-AF336969 \\
\hline CN3655 & $\mathrm{J}$ & 01966 & Hap. $1^{a}$ & AF336949-AF336950-AF336969 \\
\hline 2006_3000M & $\mathrm{J}$ & 41966 & Hap. 3 & EF667472 \\
\hline 2001_3008M & $\mathrm{J}$ & 41966 & Hap. 3 & EF667472 \\
\hline 2002_3001M & $\mathrm{J}$ & 41966 & Hap. 5 & EF667470 \\
\hline 2001_3018M & $\mathrm{J}$ & 41966 & Hap. 5 & EF667470 \\
\hline 2004_3004L & $\mathrm{J}$ & 41966 & Hap. $6^{\text {b }}$ & AF336952 \\
\hline 2001_3021N & $\mathrm{J}$ & 41966 & Hap. $6^{\text {b }}$ & AF336952 \\
\hline 2003_3007L & $\mathrm{J}$ & 41966 & Hap. $6^{\text {b }}$ & AF336952 \\
\hline 2002_3002M & $\mathrm{J}$ & 41966 & Hap. $6^{\text {b }}$ & AF336952 \\
\hline 2001_3000M & $\mathrm{J}$ & 41966 & Hap. $6^{\mathrm{b}}$ & AF336952 \\
\hline 2003_3013N & $\mathrm{J}$ & 41966 & Hap. $6^{\text {b }}$ & AF336952 \\
\hline $2003 \_3001 \mathrm{~N}$ & $\mathrm{~J}$ & 41966 & Hap. $6^{\mathrm{b}}$ & AF336952 \\
\hline 2003_3011N & $\mathrm{J}$ & 41966 & Hap. $6^{\text {b }}$ & AF336952 \\
\hline 2001_3012M & $\mathrm{J}$ & 41966 & Hap. $6^{\text {b }}$ & AF336952 \\
\hline 2001_3001M & $\mathrm{J}$ & 41966 & Hap. $6^{\text {b }}$ & AF336952 \\
\hline 2003_3016M & $\mathrm{J}$ & 41966 & Hap. $6^{\text {b }}$ & AF336952 \\
\hline 2001_3005M & $\mathrm{J}$ & 41966 & Hap. $6^{\text {b }}$ & AF336952 \\
\hline 2006_3009L & $\mathrm{J}$ & 41966 & Hap. $6^{\mathrm{b}}$ & AF336952 \\
\hline 2001_3016M & $\mathrm{J}$ & 41966 & Hap. $6^{\text {b }}$ & AF336952 \\
\hline 2001_3017M & $\mathrm{J}$ & 41966 & Hap. $6^{\text {b }}$ & AF336952 \\
\hline 8007 & $\mathrm{~J}$ & 41966 & Hap. $6^{\text {b }}$ & AF336952 \\
\hline 2001_3004M & $\mathrm{J}$ & 41966 & Hap. $6^{\text {b }}$ & AF336952 \\
\hline 2001_3009M & $\mathrm{J}$ & 41966 & Hap. $6^{\text {b }}$ & AF336952 \\
\hline 2005_3005L & $\mathrm{J}$ & 41966 & Hap. $6^{\mathrm{b}}$ & AF336952 \\
\hline 2001_3002M & $\mathrm{J}$ & 41966 & Hap. $6^{\text {b }}$ & AF336952 \\
\hline 2001_3022M & $\mathrm{J}$ & 41966 & Hap. $6^{\text {b }}$ & AF336952 \\
\hline 2001_3003M & $\mathrm{J}$ & 41966 & Hap. $6^{\text {b }}$ & AF336952 \\
\hline 2003_3010M & $\mathrm{J}$ & 41966 & Hap. $6^{\mathrm{b}}$ & AF336952 \\
\hline 2003_3015L & $\mathrm{J}$ & 41966 & Hap. $6^{\mathrm{b}}$ & AF336952 \\
\hline 2001_3015M & $\mathrm{J}$ & 41966 & Hap. $6^{\text {b }}$ & AF336952 \\
\hline 2001_3014M & $\mathrm{J}$ & 41966 & Hap. $6^{\mathrm{b}}$ & AF336952 \\
\hline 2003_3000M & $\mathrm{J}$ & 41966 & Hap. $6^{\text {b }}$ & AF336952 \\
\hline 2002_3000M & $\mathrm{J}$ & 41966 & Hap. $6^{\text {b }}$ & AF336952 \\
\hline S1 & $\mathrm{J}$ & O1966 & Hap. $6^{\mathrm{b}}$ & AF336952 \\
\hline $\mathrm{S} 2$ & $\mathrm{~J}$ & 01966 & Hap. $6^{\text {b }}$ & AF336952 \\
\hline 2005_3003M & S & 41966 & Hap. $1^{\text {a }}$ & AF336949-AF336950-AF336969 \\
\hline $2005 \_3000$ & s & 41966 & Hap. $1^{a}$ & AF336949-AF336950-AF336969 \\
\hline 2004_3001L & $\mathrm{s}$ & 41966 & Hap. $1^{a}$ & AF336949-AF336950-AF336969 \\
\hline $2005 \_3008 \mathrm{M}$ & $\mathrm{s}$ & 41966 & Hap. $1^{a}$ & AF336949-AF336950-AF336969 \\
\hline $2005 \_3007 \mathrm{M}$ & $\mathrm{s}$ & 41966 & Hap. $1^{a}$ & AF336949-AF336950-AF336969 \\
\hline
\end{tabular}


Table 1. Continued.

\begin{tabular}{|c|c|c|c|c|}
\hline Sample code & Source $(\mathrm{J}, \mathrm{S}, \mathrm{L})$ & Date (01966/41966) & Haplotype (number) & Haplotype (GB accession number) \\
\hline 2003_3006N & $\mathrm{S}$ & 41966 & Hap. $1^{\mathrm{a}}$ & AF336949-AF336950-AF336969 \\
\hline 2002_3003M & $\mathrm{S}$ & 41966 & Hap. $1^{a}$ & AF336949-AF336950-AF336969 \\
\hline 2006_3008M & $\mathrm{S}$ & 41966 & Hap. $1^{\mathrm{a}}$ & AF336949-AF336950-AF336969 \\
\hline 2005_3002M & $\mathrm{S}$ & 41966 & Hap. $1^{\text {a }}$ & AF336949-AF336950-AF336969 \\
\hline 2001_3024N & $\mathrm{S}$ & 41966 & Hap. $1^{\mathrm{a}}$ & AF336949-AF336950-AF336969 \\
\hline 2003_3003M & $\mathrm{S}$ & 41966 & Hap. $1^{\mathrm{a}}$ & AF336949-AF336950-AF336969 \\
\hline 2006_3013M & $\mathrm{S}$ & 41966 & Hap. $1^{\mathrm{a}}$ & AF336949-AF336950-AF336969 \\
\hline M7208 & $\mathrm{S}$ & 41966 & Hap. $1^{\mathrm{a}}$ & AF336949-AF336950-AF336969 \\
\hline 2006_3007M & $\mathrm{S}$ & 41966 & Hap. $1^{\mathrm{a}}$ & AF336949-AF336950-AF336969 \\
\hline $4 D^{-}$ & $\mathrm{S}$ & O1966 & Hap. $1^{\text {a }}$ & AF336949-AF336950-AF336969 \\
\hline S5 & $\mathrm{S}$ & 01966 & Hap. $1^{\mathrm{a}}$ & AF336949-AF336950-AF336969 \\
\hline $8407 \mathrm{M}$ & $\mathrm{S}$ & 01966 & Hap. $1^{\text {a }}$ & AF336949-AF336950-AF336969 \\
\hline $1 \mathrm{~A}$ & $\mathrm{~S}$ & O1966 & Hap. $1^{\mathrm{a}}$ & AF336949-AF336950-AF336969 \\
\hline $3 C$ & $\mathrm{~S}$ & 01966 & Hap. $1^{\mathrm{a}}$ & AF336949-AF336950-AF336969 \\
\hline $6 \mathrm{~F}$ & $\mathrm{~S}$ & O1966 & Hap. $1^{\mathrm{a}}$ & AF336949-AF336950-AF336969 \\
\hline $5 E$ & $\mathrm{~S}$ & 01966 & Hap. $1^{\mathrm{a}}$ & AF336949-AF336950-AF336969 \\
\hline $8431 \mathrm{M}$ & $\mathrm{S}$ & 01966 & Hap. $1^{\mathrm{a}}$ & AF336949-AF336950-AF336969 \\
\hline 2003_3008M & S & 41966 & Hap. 2 & EF667469 \\
\hline $18 \overline{3} 7$ & $\mathrm{~S}$ & O1966 & Hap. 4 & EF667471 \\
\hline 1304 & S & 01966 & Hap. $6^{\mathrm{b}}$ & AF336952 \\
\hline 2006_3003L & $\mathrm{L}$ & 41966 & Hap. $1^{\mathrm{a}}$ & AF336949-AF336950-AF336969 \\
\hline 2006_3002M & L & 41966 & Hap. $1^{a}$ & AF336949-AF336950-AF336969 \\
\hline 2006_3004N & L & 41966 & Hap. $1^{\mathrm{a}}$ & AF336949-AF336950-AF336969 \\
\hline 2005_3006M & L & 41966 & Hap. $6^{\mathrm{b}}$ & AF336952 \\
\hline 2006_3005M & L & 41966 & Hap. $7^{\mathrm{C}}$ & AF336961 \\
\hline 2006_3006M & $\mathrm{L}$ & 41966 & Hap. $7^{\mathrm{C}}$ & AF336961 \\
\hline AF336968 & GenBank & - & - & - \\
\hline
\end{tabular}

The samples dated collected before 1966 are considered to be ancient, whereas those collected after are considered to be recent. Gray cells in the date column indicate ancient samples.

${ }^{\text {a }}$ Same haplotype as Hap. a, b and u from Davison et al. (2001).

${ }^{\mathrm{b}}$ Same haplotype as Hap. d from Davison et al.

'Same haplotype as Hap. $m$ from Davison et al.

\section{Analyses}

Identical haplotypes among the sequences were determined using the Collapse tool - Collapse ver. 1.1. (Posada \& Crandall, 1998) (http://darwin.uvigo.es/software/model test.html).

Nucleotide (p) and haplotype $\left(\mathrm{H}_{\mathrm{d}}\right)$ diversity, and $\mathrm{F}_{\mathrm{ST}}$ (analogous to Wright's fixation index or $\mathrm{F}_{\mathrm{ST}}$ used for mtDNA sequences estimated by pairwise differences) values were estimated by Arlequin ver. 3.0 (Excoffier, Laval \& Schneider, 2005) (http://cmpg.unibe.ch/software/arlequin3/).

A mitochondrial genealogical relationship network was constructed using TCS ver. 2.1 (Clement, Posada \& Crandall, 2000).

\section{Results}

Eight haplotypes were found in the present work (including that from GenBank). Two of them were the main haplotypes that are shared by individuals from Jutland, Sealand and southern Scania. Within regions, four haplotypes were found in Jutland, four in Sealand and three in southern Scania. Jutland had two unique haplotypes; Sealand had two unique haplotypes, one of which belongs to a museum specimen; and finally southern Scania had one unique haplotype (see Fig. 1). For the fragment of CR used in our work (242 bp), the Hap. a, b and u described by Davison et al. (2001) are shared with our main haplotype (Hap. 1), the Hap. $d$ is shared with our second most common haplotype (Hap. 6) and the Hap. $m$ is shared with our Hap. 7, which is exclusive for southern Scania in our samples.

Southern Scania showed the highest values of nucleotide $\mathrm{p}$ and $\mathrm{H}_{\mathrm{d}}$ (recent samples $=6$, ancient samples $=0$; $\mathrm{p}=0.0102 ; \mathrm{H}_{\mathrm{d}}=0.73$ ), followed by Jutland (recent samples $=47$, ancient samples $=5 ; \mathrm{p}=0.0033 ; \mathrm{H}_{\mathrm{d}}=0.56$ ) and Sealand (recent samples $=16$, ancient samples $=10$; $\mathrm{p}=0.0013 ; \mathrm{H}_{\mathrm{d}}=0.22$ ).

Pairwise $F_{S T}$ values were all significant (PO0.05) for the three regions: Jutland versus Sealand (0.304), Jutland versus southern Scania (0.326) and Sealand versus southern Scania (0.358). Pairwise $F_{S T}$ values including Sweden, Germany and the Netherlands haplotypes (Davison et al., 2001) were not significant between southern Scania and these three 


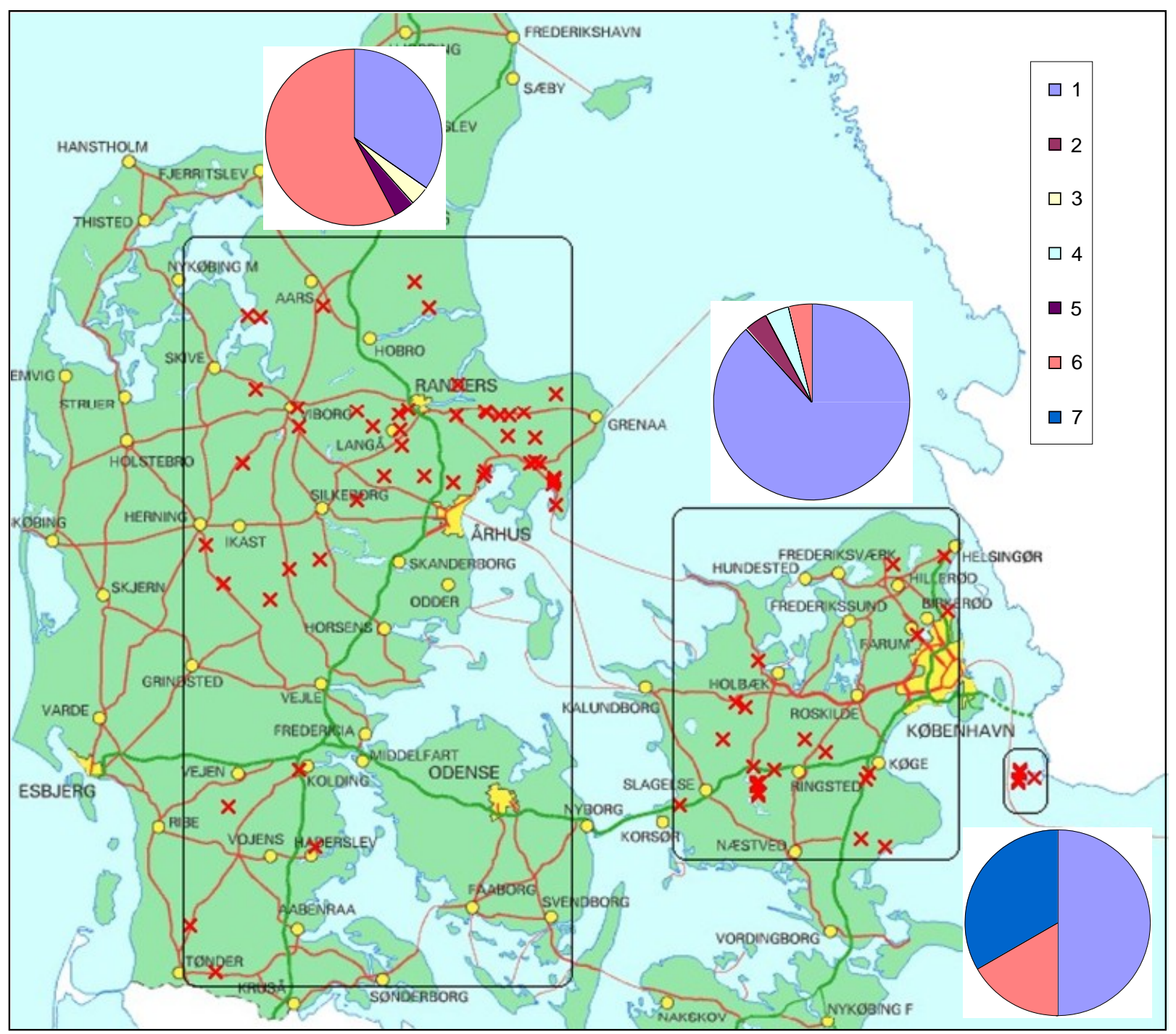

Figure 1 Localities of collection of the blood and tissue samples (indicated by an X), which were subdivided into three geographical distinct regions: Jutland (left area), Sealand (central area) and southern Scania (right area). The frequency distribution of the haplotypes in each region is shown. Note that two main haplotypes are present in all the regions, and that each region has unique haplotypes.

countries, but interestingly the $\mathrm{F}_{\mathrm{ST}}$ value was 0.194 with a quasi-significant $\mathrm{P}$-value $(\mathrm{P}=0.062)$ between southern Scania (Sweden) in our study and central Sweden in the study of Davison et al. (2001).

The mitochondrial genealogical relationship net constructed using TCS ver. 2.1 shows a network of the distinct haplotypes, which is depicted in Fig. 2.

\section{Discussion}

Relatively low values of $\mathrm{H}_{\mathrm{d}}$ and $\mathrm{p}$ were found in general both for Jutland and for Sealand, although southern Scania had the highest values in spite of the low number of recent samples and no ancient samples. The $\mathrm{p}$ value of southern Scania $(p=0.0102)$ is one order of magnitude higher than for the other two regions and it is comparable to the average nucleotide diversity found by Davison et al. (2001) for the pine marten $(0.013$, sD $=0.001)$. The $\mathrm{p}$ values for Jutland and Sealand are quite similar to the $\mathrm{p}$ found for the Danish polecat Mu. putorius by Pertoldi et al. (2006b) $(p=0.00274)$ and are relatively small compared with estimates obtained for other carnivores, as for example the sea otter Enhydra lutris with $\mathrm{p}=0.098$ (Larson et al., 2002), the Steller sea lion Eumetopias jumbatus with $\mathrm{p}=1.7$ (Bickham, Patton \& Loughlin, 1996) or the dog Canis familiaris with $\mathrm{p}=1.30$ (Randi et al., 2000). The $\mathrm{H}_{\mathrm{d}}$ found for Jutland and southern Scania is quite similar to the $\mathrm{H}_{\mathrm{d}}$ found for the Danish polecat by Pertoldi et al. (2006b) $\left(\mathrm{H}_{\mathrm{d}}=0.876\right)$, but they are higher than the $\mathrm{H}_{\mathrm{d}}$ found for the European mink Mustela lutreola with $H_{d}=0.469$ (Michaux et al., 2005), the sea otter 


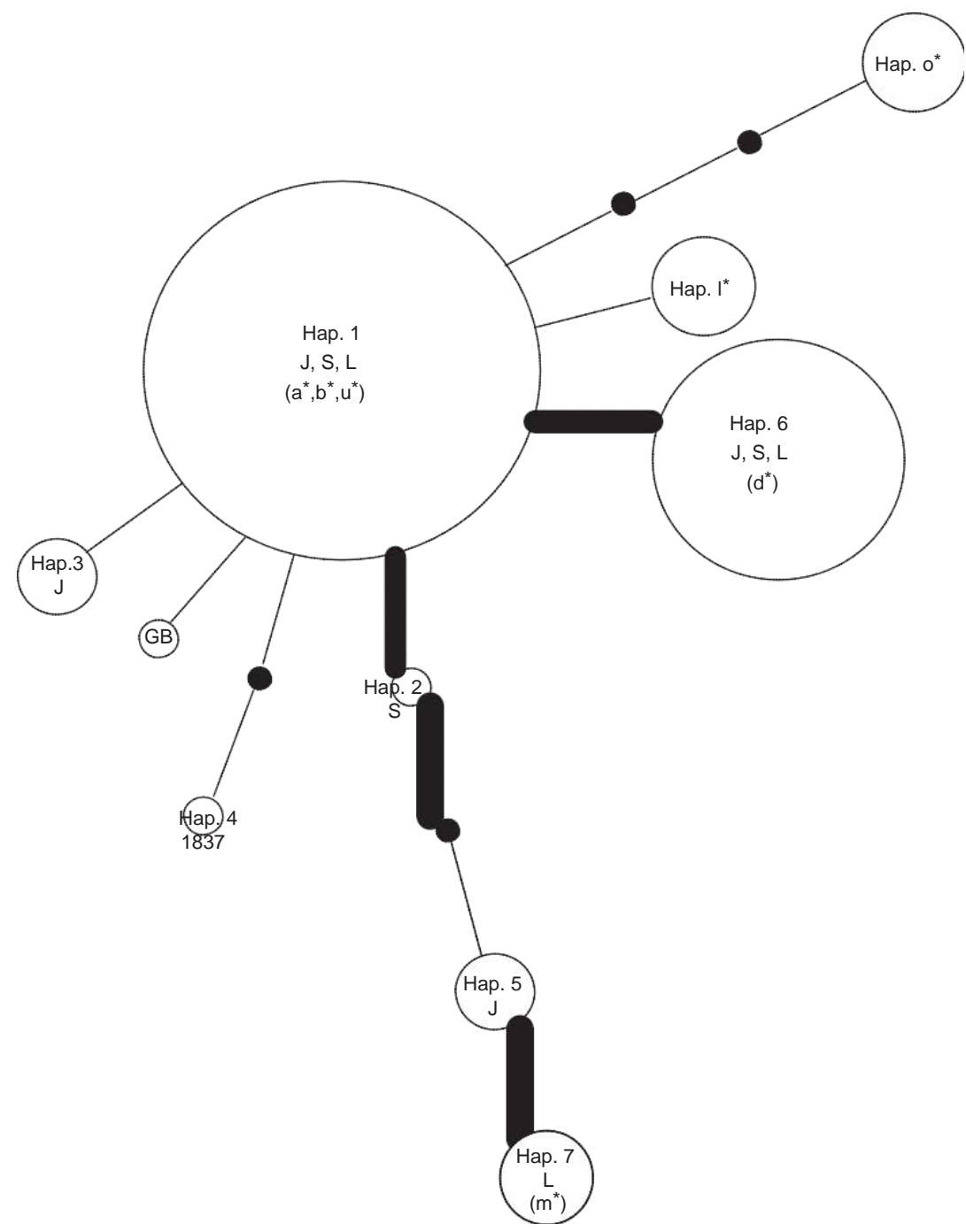

Figure 2 Network of haplotypes in a total of 85 sequences from a fragment of the control region of Danish pine martens Martes martes (242 bp). Six haplotypes described by Davison et al. (2001) are also depicted in the figure. J, Jutland; S, Sealand; L, southern Scania/S. Sweden; GB, GenBank sequence (AF336968); 1837, ID of one ancient specimen from Sealand. The circle is proportional to the frequency of the haplotype. The black circle indicates a lost ancestral or nonsampled haplotype. ${ }^{\times}$Haplotypes from Davison et al. (2001). with $\mathrm{H}_{\mathrm{d}}=0.412$ (Larson et al., 2002), the Eurasian otter L. lutra with $\mathrm{H}_{\mathrm{d}}=0.16$ (Ferrando et al., 2004) or the dog with $\mathrm{H}_{\mathrm{d}}=0.76$ (Randi et al., 2000).

It was not possible to see genetic structure in the genealogical relationships, probably due to the low mitochondrial diversity observed for this species, and for Mustelids in general, and due to a rapid recolonization or successive waves of colonization after the last Pleistocene glaciation. As suggested by Davison et al. (2001), this species probably survived in one single refuge where some haplotypes were predominantly present and others were rarer. At the end of the last ice age, the most common haplotypes recolonized all Europe and the rarest ones were dispersed all over this region following stochastic processes. It is for this reason that presently these haplotypes are not equally distributed but rather present a random distribution. A recent expansion process, after a period with reduced population size, could explain the combination of high $\mathrm{H}_{d}$ and low $\mathrm{p}$ (Stamatis et al., 2004). A period of reduced population size could also explain the presence of a 'ghost' unique haplotype from an ancient specimen (1837; see Table 1) in Sealand.

$\mathrm{F}_{\mathrm{ST}}$ values, based on microsatellite data, within and between Jutland and Sealand regions were found to be relatively high in both ancient and recent samples (Pertoldi et al., 2008). The differentiation in $F_{S T}$ values is also reflected at the mitochondrial level by the $F_{S T}$ values, supporting the historical differentiation between the three regions of study.

If the $\mathrm{F}_{\mathrm{ST}}$ value (marginal-significant) obtained for southern Scania versus central Sweden depended on the number of samples from southern Scania, this could mean that southern Scania and central Sweden are differentiated, and that the haplotypes from Lund are more related to those from Germany and the Netherlands than to those from Sweden. However, given the relatively small sample size of southern Scania $(n=6)$, the values of $F_{S T}$ should be considered very cautiously. Hence, in this scenario, our results suggest that at least three different haplotype groups exist in 
central and northern Europe, probably as a consequence of a leptokurtic dispersal following recolonization after the last glaciation from different European refugia, or due to fragmentation and isolation processes as has been proposed for other mustelids (Ibrahim, Nichols \& Hewitt, 1996; Davison et al., 2001). Unfortunately, the limited values of $\mathrm{H}_{\mathrm{d}}$ found for the Danish pine marten populations are limiting the kind of analyses (e.g. mismatch distribution and coalescent approaches) that would have allowed a deeper insight into their demographic history.

\section{Acknowledgements}

This research project has been supported by a Marie Curie Transfer of Knowledge Fellowship BIORESC of European Community's Sixth Framework Programme under contract number MTKD-CT-2005-029957. Furthermore, we wish to thank the ConGen program (funded by the European Science Foundation) and the Danish Natural Science Research Council for financial support to CP (grant number: \#21-010526 and \#21-03-0125). We are grateful to the Natural History Museum, Aarhus, the Zoological Museum, Lund University, the Natural History Museum of Denmark, Zoological Museum, Copenhagen, and the National Environmental Research Institute, University of Aarhus for access to their collections. Finally, we thank T. Lode and one anonymous reviewer for invaluable suggestions and comments.

\section{References}

Aaris-Sørensen, K. (2007). Fra istid til nutid. In Dansk Pattedyratlas: 312-321. Baagøe, H.J. \& Jensen, T.S. (Eds). Copenhagen, Denmark: Gyldendal. (English summary).

Bickham, J.W., Patton, J.C. \& Loughlin, T.R. (1996). High variability for control-region sequences in a marine mammal: implications for conservation and biogeography of Steller sea lions Eumetopias jubatus. J. Mammal. 77, 95-108.

Bright, P.W. (2000). Lessons from lean beats: conservation biology of the mustelids. Mammal Rev. 30, 217-226.

Caspersen, O.H. (2001). Landbrug og landskab. In Grænser i landskabet: 111-134. Hels, T., Frandsen, J.N., Fritzbøger, B. \& Olesen, C.R. (Eds). Odense, Denmark: Odense University Press (in Danish).

Clement, M.D., Posada, D. \& Crandall, K.A. (2000). TCS: a computer program to estimate gene genealogies. Mol. Ecol. 9, 1657-1659.

Davison, A., Birks, J.D., Brookes, R.C., Messenger, J.E. \& Griffiths, H.I. (2001). Mitochondrial phylogeography and population history of pine martens Martes martes compared with polecats Mustela putorius. Mol. Ecol. 10, 2479-2488.

Degn, H.J. \& Jensen, B. (1977). Skovmaren (Martes martes) i Danmark. Danske Vildtundersøgelser 29.

Domingo-Roura, X. (2002). Genetic distinction of marten species by fixation of a microsatellite region. J. Mammal. 83, 907-912.
Excoffier, L., Laval, G. \& Schneider, S. (2005). Arlequin ver. 3.0: an integrated software package for population genetics data analysis. Evol. Bioinform. Online 1, 47-50.

Ferrando, A., Ponsa, M., Marmi, J. \& Domingo-Roura, X. (2004). Eurasian otters, Lutra lutra, have a dominant mtDNA haplotype from the Iberian Peninsula to Scandinavia. J. Hered. 95, 430-435.

Ibrahim, K.M., Nichols, R.A. \& Hewitt, G.M. (1996). Spatial patterns of genetic variation generated by different forms of dispersal during range expansion. Heredity 77, 282-291.

Kyle, C.J., Davis, C. \& Strobeck, C. (2000). Microsatellite analysis of North American pine marten Martes americana populations from the Yukon and Northwest Territories. Can. J. Zool. 78, 1150-1157.

Larson, S., Jameson, R., Bodkin, J., Staedler, M. \& Bentzen, P. (2002). Microsatellite DNA and mitochondrial DNA variation in remnant and translocated sea otter Enhydra lutris populations. J. Mammal. 83, 893-906.

Madsen, A.B., Ujvari, M., Elmeros, M. \& Asferg, M. (2007). Skovmar Martes martes (Linnaeus, 1758). In Dansk Pattedyratlas: 206-209. Baagøe, H.J. \& Jensen, T.S. (Eds). Copenhagen, Denmark: Gyldendal.

Michaux, J.R., Hardy, O.J., Justy, F., Fournier, P., Kranz, A., Cabria, M., Davison, A., Rosoux, R. \& Libois, R. (2005). Conservation genetics and population history of the threatened European mink Mustela lutreola, with an emphasis on the West European population. Mol. Ecol. 14, 2373-2388.

Mitchell-Jones, A., Amori, G., Bogdanowicz, W., Krystufek, B., Reijnders, P.J.H., Spitzenberger, F., Stubbe, M., Thissen, J.B.M., Vohralik, V. \& Zima, J. (1999). The atlas of European mammals. San Diego: Academic Press Inc.

Nielsen, E.E., Hansen, M.M. \& Loeschcke, V. (1999). Analysis of DNA from old scale samples: technical aspects, applications and perspectives for conservation. Hereditas 130, 265-276.

Pertoldi, C., Barker, J.S.F., Madsen, A.B., Jørgensen, H., Randi, E., Munoz, J., Baagoe, H.J. \& Loeschcke, V. (2008). Spatio-temporal population genetics of the Danish pine marten (Martes martes). Biol. J. Linn. Soc. 93, 457-464.

Pertoldi, C., Breyne, P.M.T., Halfmaerten, D., Jansman, A.H., Van Den Berge, K., Madsen, A.B. \& Loeschcke, V. (2006b). Genetic structure of the European polecat Mustela putorius and its implication for conservation strategies. J. Zool. (Lond.) 270, 102-115.

Pertoldi, C., Hansen, M.M., Loeschcke, V., Madsen, A.B., Jacobsen, L. \& Baagoe, H. (2001). Genetic consequences of population decline in European Otter Lutra lutra: an assessment of microsatellite DNA variation in Danish Otters from 1883-1993. Proc. Roy. Soc. Lond. B 268, 1775-1781.

Pertoldi, C., Loeschcke, V., Randi, E., Madsen, A.B., Hansen, M.M., Bijlsma, R. \& Van De Zande, L. (2005). Present and past microsatellite variation and assessment of genetic structure in Eurasian badger Meles meles in Denmark. J. Zool. (Lond.) 265, 387-394.

Pertoldi, C., Norup, A.M., Madsen, A.B., Baagoe, H., Randi, E. \& Loeschcke, V. (2006a). No evidence of past 
bottlenecks in two Danish mustelids: results of the craniometric and genetic studies in time and space. Biol. J. Linn. Soc. 88, 541-553.

Posada, D. \& Crandall, K.A. (1998). Modeltest: testing the model of DNA substitution. Bioinformatics 14, 817-818.

Randi, E., Lucchini, V., Christensen, M.F., Mucci, N., Funk, S.M., Dolf, G. \& Loeschcke, V. (2000). Mitochondrial DNA variability in Italian and east European wolves: detecting the consequences of small population size and hybridisation. Conserv. Biol. 14, 464-473.
Shields, G.F. \& Kocher, T.D. (1991). Phylogenetic relationships of North-American ursids based on analysis of mitochondrial DNA. Evolution 45, 218-221.

Stamatis, C., Triantafyllidis, A., Moutou, A. \& Mamuris, Z. (2004). Mitochondrial DNA variation in Northeast Atlantic and Mediterranean populations of Norway lobster, Nephrops norvegicus. Mol. Ecol. 13, 1377-1390.

Stoltze, M. \& Pihl, S. (1997). Rødliste 1997 over planter og dyr i Danmark. http://sns.dk/roedliste/roedliste1997. 